\title{
A study to compare acceptability, safety and continuation rates of combined hormonal pill and centchroman as post abortion contraceptives
}

\author{
Inlo Miuli*, Rupali Dewan, Kavita Agarwal
}

Department of Obstetrics and Gynecology, VMMC and Safdarjung, New Delhi, India

Received: 22 March 2020

Revised: 26 May 2020

Accepted: 02 June 2020

\author{
*Correspondence: \\ Dr. Inlo Miuli, \\ E-mail: inlomiuli@gmail.com
}

Copyright: (C) the author(s), publisher and licensee Medip Academy. This is an open-access article distributed under the terms of the Creative Commons Attribution Non-Commercial License, which permits unrestricted non-commercial use, distribution, and reproduction in any medium, provided the original work is properly cited.

\begin{abstract}
Background: Centchroman a non-steroidal selective estrogen receptor modifier (SERM). It is highly effective contraceptive which is devoid of side effects of COCs and there is prompt return of fertility upon discontinuation. Data in terms of its acceptability and continuation rates is limited when compared to combined oral contraceptive (COC). Therefore, the study was planned to study the acceptability, efficacy and continuation rates of centchroman and compare it with the combined oral contraceptives.

Methods: The study was a prospective interventional comparative randomized study carried out in the department of obstetrics and gynecology VMMC and SJH, New Delhi, for a period of 18 months from November 2018 to April 2019.

Results: A total of 945 women were screened and finally 240 women who met the criteria were recruited in 2 study groups of 120 women each. Majority were in the age group 18-28 years in either groups. Patients were followed up at $2^{\text {nd }}$ week and then at $1^{\text {st }}, 3^{\text {rd }}, 6^{\text {th }}$ and $12^{\text {th }}$ months after initiation of the OCP with no loss to follow up. The pearl index in this study was 0.83 for ormeloxifene. The study showed statistically significant differences with higher level of satisfaction reported with $77.5 \%$ in the ormeloxifene compared to $65 \%$ of COCs. The continuation rates for ormeloxifene and COC users were in decreasing trend with increase in duration. No untoward events were reported with either formulation.

Conclusions: Both the hormonal, combined hormonal contraceptive [combined oral contraceptive (COC), MALA-N] and the non-hormonal, centchroman (ormeloxifene) oral contraceptive pills are safe, effective, well tolerated and not associated with adverse outcomes when used immediately after abortion. Continuation rates of the pills in both the groups decrease in trend with time.
\end{abstract}

Keywords: Centchroman, Hormonal oral contraceptive pill, Pearl index, Postabortal contraception

\section{INTRODUCTION}

Globally, around 210 million women become pregnant each year, of which 75 million pregnancies end up in either induced or spontaneous abortion. ${ }^{1}$ World health organisation (WHO) also recommends spacing of at least 6 months between abortion and next pregnancy. Providing family planning services as a part of post- abortion care can improve contraceptive acceptance and help break the cycle of repeated unwanted pregnancies.

Combined hormonal contraceptives (CHCs) have been available for over 50 years. During ideal use combined oral contraceptive (COC) offer very good protection against unwanted pregnancies, however there is a big problem with compliance and continuation and thus the 
'real-life' efficacy is much lower. Reasons for poor compliance include side effects and fear of adverse effects and it is crucial that the prescriber gives the individual woman thorough and balanced information on the benefits and risks.

Centchroman is a non-steroidal selective estrogen receptor modifier (SERM) with strong antiestrogen and weak estrogenic and antiprogestin properties. ${ }^{2}$ Centchroman is highly effective contraceptive which is devoid of side effects of COCs and there is prompt return of fertility upon discontinuation. It is these beneficial effects as well as the less frequent dosing with fixed days of regimen of centchroman which makes it a better oral contraceptive option. Despite being highly effective and safe oral contraceptive with convenient dosing schedule, it has not gained much popularity.

Government of India (GOI) has initiated efforts to expand the existing basket of choices by adding centchroman (Ormeloxifene) in the National family Planning Programme in 2016 with the name Chhaya. ${ }^{3}$

Data in terms of its acceptability and continuation rates is limited when compared to combined oral contraceptive (COC). Therefore, the present study is planned to study the acceptability, efficacy and continuation rates of centchroman and compare it with the combined oral contraceptives.

Authors also plan to study the oral contraceptive usage pattern. The result of study will enable us to understand acceptability, usage pattern and associated barriers.

\section{METHODS}

This was prospective interventional comparative randomized study. The study was carried out in the department of obstetrics and gynecology VMMC and SJH, from November 2018 to April 2019, for a period of 18 months.

- Period for recruitment of the subjects: 6 months

- Period required for follow-up: 12 months

On the basis of previous study, Nupur G et al efficacy rate of COC was $0.3 \%$ and of Centchroman was $1.63 \% .^{4}$

Taking these values as reference, the minimum required sample size with $80 \%$ power of study and $5 \%$ level of significance is 845 patients in each study group.

\section{Formula used}

$$
n \geq \frac{p c(1-p c)+\mathrm{pE}(1-\mathrm{pE})}{\delta_{0}^{2}}(Z+Z \beta)^{2}
$$

$\mathrm{pc}=$ Efficacy rate of $\mathrm{COC}$

$\mathrm{pE}=$ Efficacy rate

$\delta_{0}=\mathrm{pE}=\mathrm{pc}$
Where $Z_{\alpha}$ is value of $\mathrm{Z}$ at two-sided alpha error of $5 \%$ and $Z_{\beta}$ is value of $Z$ at power of $80 \%$.

Due to time constraint and non-availability of large number of patients, authors are using convenient sampling technique. On the basis of hospital records, there are approximately 2000 abortions in the institute per year, out of which $15 \%$ fulfills eligibility criteria. Assuming the dropout rate is $20 \%$, the total sample size will be 240 (120 patients per group).

\section{Assessment and screening of patient}

- First screening of the women opting for postabortion oral contraception was done as per WHO MEC Criteria

- $\quad$ All the women after a complete spontaneous/induced abortion by medical/surgical method at $1^{\text {st }} / 2^{\text {nd }}$ trimester and desirous of post abortion contraceptive were given information about all contraceptive methods available using suitable IEC (information, education and communication) materials and models.

- The women willing for post abortion contraception method were asked to choose the method most convenient for her

- Eligible women were further counseled and given information regarding $\mathrm{COC}$ i.e. MALA-N and centchroman with the information of advantages and disadvantages of each method

- Women willing to start the OCP were finally enrolled in this study.

\section{Inclusion criteria}

- Women with spontaneous /induced abortion

- Willing to use CHC or centchroman as oral postabortion contraceptive

- Willing to participate and follow up in the study.

\section{Exclusion criteria}

- Women with history of polycystic ovarian disease

- Cervical hyperplasia

- Recent history or clinical evidence of jaundice or liver disease

- Severe allergic states

- Chronic illness such as tuberculosis or renal disease

- Women belonging to WHO MEC category 3 OR 4 for $\mathrm{CHC}$

- $\quad$ Evidence of RPOCS

- Any malignancy.

\section{Sample size}

A total of 945 women were screened at pre and immediate post abortion period. Of the given choices 534 women opted for OCP and 411 opted for other methods. The number of women willing for participation were remaining 288. Finally, 240 women met the criteria for 
the study and were recruited. After the block randomization both the study groups consisted of 120 women.

\section{Method of randomization}

Block randomization was done and women were enrolled into 2 groups.

\section{Study population}

Group A: One twenty women undergoing management for spontaneous / induced abortion willing to take COC: MALA-N

Group B: One twenty women undergoing management for spontaneous/induced abortion willing to take centchroman (ormeloxifene).

Written informed consent was taken from all the subjects in the language understood by them as per Annexure I.

\section{Examination and investigation}

All the information of the subjects enrolled in the study was noted in a proforma before starting the dose.

\section{Initiation of OCPs}

Mala - N: first dose at day 1 of surgical abortion or day 3 of medical abortion; 1 tablet daily for 21 days followed by 7 days of ferrous fumarate.

Centchroman: First dose at day 1 of surgical abortion or day 3 of medical abortion. It is to be taken 2 fixed days a week for 3 months followed by 1 fixed day/week every month thereafter.

\section{Post pill instruction}

\section{Missed pill management of MALA-N}

- Missed 1 or 2 pills/started new pack 1 or 2 days lateTake 1 pill as soon as possible or two pills at scheduled time

- Missed 3 or more pills in the first or second week/started new pack 3 or more days late-Take 1 pill as soon as possible and continue the scheduled pill. Use a backup method for the next 7 days. Also, can consider taking ECPs, if she had sex in the past 72 hours

- Missed 3 or more pills in the third week- Take one hormonal pill as soon as possible and finish all hormonal pills in the pack as scheduled. Throw away the 7 non-hormonal pills in a 28-pill pack. Start a new pack the next day. Use a backup method for the next 7 days. Also, can consider taking ECPs, if she had sex in the past 72 hours

- Missed any nonhormonal pills (last 7 pills in 28-pill pack)-discard the missed non-hormonal pill(s). Keep taking COCs, one each day. Start the new pack as usual

- $\quad$ Severe vomiting or diarrhea- If she vomits within 2 hours after taking a pill, she should take another pill from pack as soon as possible and continue taking the scheduled pills.

- If she has vomiting or diarrhoea for more than 2 days, follow instructions for 1 or 2 missed pills above.

\section{Missed pill management of centchroman (CHHAYA)}

- Take a pill as soon as possible after it is missed

- If pill is missed by 1 or 2 days but lesser than 7 days, the normal schedule should be continued and client needs to use a back-up method (e.g. condoms) till the next period starts

- If pill is missed by more than 7 days, client needs to start taking it all over again like a new user that is twice a week for 3 months and then once a week

\section{Follow up visits}

All women starting on the pill as the method of postabortal contraception were called for follow-up visits after 2 weeks of starting dose and then further visits after $1^{\text {st }}, 3^{\text {rd }}, 6^{\text {th }}$ and $12^{\text {th }}$ months.

\section{Outcome measures}

\section{Primary outcome}

Efficacy: pearl index (PI) or pearl rate is the standard method for measuring the failure rates and thus helps in comparison of effectiveness of different contraceptive methods.

$$
\begin{aligned}
& \text { Pearl }- \text { index } \\
& =\frac{\text { Number of pregnancies } \times 12}{\text { Number of women } \times \text { Number of months }} \times 100
\end{aligned}
$$

\section{Acceptability}

Satisfaction with OCPs and recommendation as contraceptive option to others.

\section{Continuation rate}

No of women continuing OCP at the end of the study (12 months).

Safety Occurring of any untoward events related to drugs.

\section{Secondary outcome}

Pill usage pattern

- Continuation- To describe pill use that is, on average, maintained daily for subsequent menstrual cycles in 
research subjects using OC as the primary method of birth control

- Discontinuation- To describe pill use that is stopped for a period of $>=7$ days and never resumed within a menstrual cycle or at onset of the following cycle in case of ormeloxifene and $>3$ days in case of $\mathrm{COC}$ pills

- Interrupted use- To describe a gap of pill nonuse for $>=7$ days during the menstrual cycle or in between packs in OC users but that is resumed within a cycle or at onset of the following cycle.

This pattern of use was irrelevant as both the drugs compared had a wide dosing schedule

- Missed pills- To describe pill use that is stopped within a menstrual cycle for $<7$-day period.

\section{Reasons of discontinuation}

\section{Statistical analysis}

All the data was collected and entered in MS excel spreadsheet and analysis was done using statistical package for social sciences (SPSS) version 21.0.

\section{RESULTS}

Age

The majority of the women were of age group 18-28 years with the mean age was $23.32 \pm 2.5$ and $25.43 \pm 3.8$ for centchroman and CHC as shown in Table 1.

Table 1: Distribution according to age.

\begin{tabular}{|llll|}
\hline $\begin{array}{l}\text { Age } \\
\text { distribution } \\
\text { (years) }\end{array}$ & $\begin{array}{l}\text { Ormeloxifene } \\
\mathbf{N}=\mathbf{1 2 0}\end{array}$ & $\begin{array}{l}\mathrm{COC} \\
\mathbf{N}=\mathbf{1 2 0}\end{array}$ & $\begin{array}{l}\mathbf{p} \\
\text { value }\end{array}$ \\
\hline $18-28$ & $85(70.83 \%)$ & $73(60.83 \%)$ & 0.102 \\
\hline $29-38$ & $35(29.16 \%)$ & $47(39.16 \%)$ & \\
\hline Mean age & $23.32 \pm 2.5$ & $25.43 \pm 3.8$ & \\
\hline
\end{tabular}

Table 2: Distribution according to education level.

\begin{tabular}{|llll|}
\cline { 1 - 2 } Literacy & $\begin{array}{l}\text { Ormeloxifene } \\
\mathbf{N}=120\end{array}$ & $\begin{array}{l}\text { COCS } \\
\mathbf{N}=120\end{array}$ & $\begin{array}{l}\text { p } \\
\text { value }\end{array}$ \\
\cline { 1 - 3 } Graduate & $15(12.5 \%)$ & $8(6.66 \%)$ & \\
\cline { 1 - 3 } Secondary & $31(25.83 \%)$ & $28(23.33 \%)$ & \\
\cline { 1 - 3 } Primary & $57(47.5 \%)$ & $73(60.83 \%)$ & \\
\cline { 1 - 3 } Uneducated & $17(14.16 \%)$ & $11(9.16 \%)$ & \\
\hline
\end{tabular}

Table 3: Distribution according to parity.

\begin{tabular}{|c|c|c|c|}
\hline Parity & $\begin{array}{l}\text { Ormeloxifene } \\
\mathrm{N}=120\end{array}$ & $\begin{array}{l}\text { COCS } \\
N=120\end{array}$ & p value \\
\hline Nulliparous & $45(37.5 \%)$ & $41(34.16 \%)$ & \multirow{4}{*}{0.658} \\
\hline 1 & $43(35.83 \%)$ & $38(31.66 \%)$ & \\
\hline 2 & $24(20 \%)$ & $31(25.83 \%)$ & \\
\hline $3+$ & $8(6.66 \%)$ & $10(8.33 \%)$ & \\
\hline
\end{tabular}

\section{Education}

Majority of the women in both the groups were educated, $85.83 \%$ in ormeloxifene and $90.83 \%$ in COCs as given in Table 2.

\section{Parity}

As shown in Table 3 majority of the women, $37.5 \%$ and $41 \%$ in ormeloxifene and COC respectively were nulliparous. Majority of the women, $53(43.33 \%)$ in the ormeloxifene group and $41(36.67 \%)$ in COC group were 5 to 6 weeks pregnant.

\section{Abortion type}

Overall spontaneous abortion was higher than induced abortion as shown in Table 4. In ormeloxifene group 88 $(73.33 \%)$ women underwent spontaneous abortion while in COC group $76(63.33 \%)$.

Table 4: Distribution according to type of abortion.

\begin{tabular}{|c|c|c|c|}
\hline $\begin{array}{l}\text { Type of } \\
\text { abortion }\end{array}$ & $\begin{array}{l}\text { Ormeloxifene } \\
\mathrm{N}=120\end{array}$ & $\begin{array}{l}\text { COC } \\
N=120\end{array}$ & $\begin{array}{l}\mathbf{p} \\
\text { value }\end{array}$ \\
\hline Spontaneous & $88(73.33 \%)$ & $76(63.33 \%)$ & \multirow{7}{*}{0.135} \\
\hline $\begin{array}{l}\text { Complete } \\
\text { abortion }\end{array}$ & $10(11.36 \%)$ & $7(9.21 \%)$ & \\
\hline Medication & $21(23.86 \%)$ & $26(34.21 \%)$ & \\
\hline Surgical & $57(64.77 \%)$ & $43(56.57 \%)$ & \\
\hline $\begin{array}{l}\text { Induced } \\
\text { (MTP)* }\end{array}$ & $32(26.66 \%)$ & $44(36.66 \%)$ & \\
\hline Medication & $12(37.5 \%)$ & $10(22.72 \%)$ & \\
\hline Surgical & $20(62.5 \%)$ & $34(77.27 \%)$ & \\
\hline
\end{tabular}

\section{Pre-initiation assessment of women}

All the participants underwent a baseline general physical, gynaecological examination and a baseline investigation. No abnormalities were detected and 1st pill was initiated. First 24 hours women were advised to rest and report if any complaints related to bleeding manifestation or physical unwell was experienced. With $1^{\text {st }}$ dose well tolerated and no adverse effects documented all the women were discharged with advice for revisit at $2^{\text {nd }}$ week or earlier if any specific pill related or gynaecological issues developed.

\section{Follow up}

Follow up at $2^{\text {nd }}$ week

All the women were followed up after 14 days from the initiation of the OCP. General well-being and experience regarding any new onset adverse event were enquired. General and physical examinations was done for all. Women who had other issues were addressed with required gynaecological examinations. 
All the women had complete abortion. Pelvic pain was reported in $7(14.16 \%)$ women in ormeloxifene and in 10 $(8.33 \%)$ of COC users. Most common side effects were bloating, $17(14.16 \%)$ in COC and in $5(4.16 \%)$ of ormeloxifene followed by nausea/vomiting in $11(9.16 \%)$ COC and in $4(3.33 \%)$ of ormeloxifene.

No untoward events were documented in both the groups.

Follow up from 1 month till 12 months
Due to time and distance constraints the subjects were allowed to visit directly at 3rd month for next follow up but earlier. If any pill related issues occurred.

\section{Pill usage pattern}

As the Table 5 shows the continuation pattern were statistically significant in difference with higher continuation usage pattern reported in ormeloxifene $(63.33 \%)$ than in COC $(46.66 \%)$ users.

Table 5: Pill usage pattern.

\begin{tabular}{|c|c|c|c|c|c|c|c|}
\hline \multirow[b]{2}{*}{ Usage pattern } & \multicolumn{2}{|l|}{$3^{\text {rd }}$ month } & \multicolumn{2}{|l|}{$6^{\text {th }}$ month } & \multicolumn{2}{|l|}{$12^{\text {th }}$ month } & \multirow[t]{2}{*}{ p value } \\
\hline & $O(N=120)$ & $\begin{array}{l}\text { COC } \\
(N=120)\end{array}$ & 118) & $\begin{array}{l}\text { COC } \\
(N=114)\end{array}$ & $\mathbf{O}(\mathbf{N}$ & $\begin{array}{l}\text { COC } \\
(\mathrm{N}=90)\end{array}$ & \\
\hline Continua & $113(94$. & $91(75.83 \%)$ & $101(85.59 \%)$ & $72(63.15 \%)$ & $74(67.27 \%)$ & $53(58.88 \%)$ & 0.0048 \\
\hline Missed & $6(5 \%)$ & $23(19.16 \%)$ & $10(8.47 \%)$ & $18(15.78 \%)$ & $25(22.72 \%)$ & $22(24.44 \%)$ & 0.1976 \\
\hline Discontinuation & $2(1.66 \%)$ & $6(5 \%)$ & $8(6.77 \%)$ & $24(20.33 \%)$ & $11(10 \%)$ & $15(16.66 \%)$ & 0.047 \\
\hline
\end{tabular}

Table 6: Continuation and discontinuation rates.

\begin{tabular}{|lllllll|}
\hline & Ormeloxifene & \multicolumn{3}{c|}{ COC } & & \\
\hline Rates (N\%) & $3^{\text {rd }}$ month & $\mathbf{6}^{\text {th }}$ month & $\mathbf{1 2}^{\text {th }}$ month & $\mathbf{3}^{\text {rd }}$ month & $\mathbf{6}^{\text {th }}$ month & $\mathbf{1 2}^{\text {th }}$ month \\
\hline Continuation & $120(100 \%)$ & $118(98.33 \%)$ & $110(91.66 \%)$ & $120(100 \%)$ & $114(95 \%)$ & $90(75 \%)$ \\
\hline Discontinuation & $2(1.66 \%)$ & $8(6.66 \%)$ & $11(9.16 \%)$ & $6(5 \%)$ & $24(20 \%)$ & $15(12.5 \%)$ \\
\hline
\end{tabular}

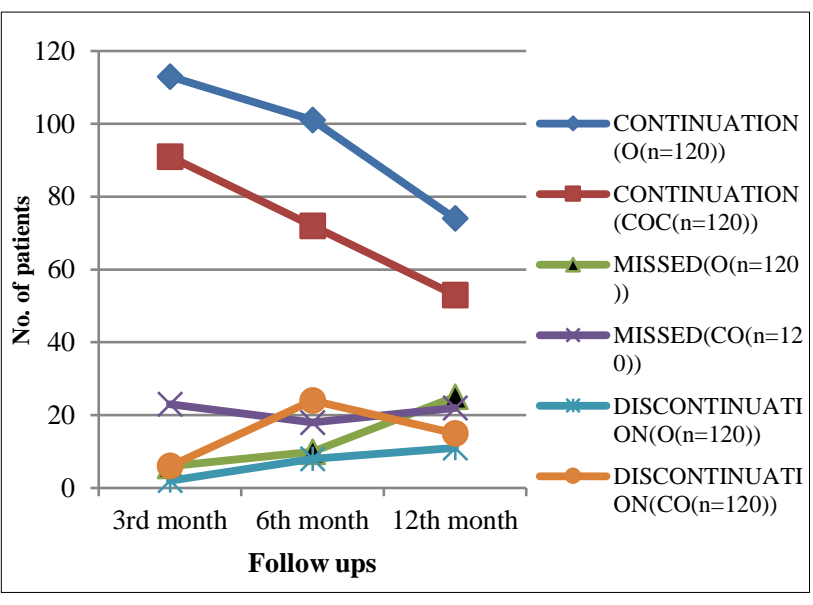

Figure 1: Pill usage pattern.

\section{Continuation and discontinuation rates}

The continuation rates for ormeloxifene and COC users were in decreasing trend with increase in duration as depicted in Table 6.

\section{Menstrual patterns}

Figo 2014 definitions were taken as reference to define the abnormalities in menstrual cycles.

\section{Menstrual cycle frequency}

The cycles with normal frequency decreased with increase duration of the study showing 115 (95.83\%), 104 $(88.13 \%)$ and $73(66.36 \%)$ in ormeloxifene while 114 $(95 \%), 110(96.49 \%)$ and $84(93.33 \%)$ in COC group at 3,6 and 12 months respectively. In ormeloxifene delayed cycles of 36-45 days and $>45$ days were documented in $15(13.63 \%)$ and $8(7.27 \%)$ women respectively. Delayed cycles of 35-45 days frequency increased in COC user with increase in duration $1(0.83 \%), 1(0.87 \%)$ and 5 $(5.55 \%)$ respectively.

Four $(3.63 \%)$ women had amenorrhea at 1 year. None of the women in COC group had amenorrhea.

\section{Menstrual cycle flow}

The amount of menstrual flow was analysed on subjective documentation. The prior amount of menstrual flow was considered normal and as reference level for any further discrepancy as either less than or more than normal. Heavy flow occurred in majority of women of COC group $6.66 \%$ at $3^{\text {rd }}$ month.

At 1 year in more women of the ormeloxifene group, cycles became scanty $25(22.2 \%)$ compared to only 7 $(7.77 \%)$ women in COC group. 


\section{Failure rates}

From Table 7 there was 1 method failure in the ormeloxifene users while no method failure were reported with COC users. There was no significant statistical difference observed. In ormeloxifene users 1 user failure was documented while 3 user failures in COC users.

Table 7: Failure rates.

\begin{tabular}{|c|c|c|c|}
\hline Failure rates & $\begin{array}{l}\text { Ormeloxifene } \\
N=120\end{array}$ & $\begin{array}{l}\text { COCS } \\
N=120\end{array}$ & $\begin{array}{l}\mathbf{p} \\
\text { value }\end{array}$ \\
\hline Method failure & $1(0.83 \%)$ & 0 & \\
\hline At $3^{\text {rd }}$ month & - & - & \\
\hline At $6^{\text {th }}$ month & - & - & \\
\hline At $12^{\text {th }}$ month & $1(100 \%)$ & - & \\
\hline User failure & $1(0.83 \%)$ & $3(2.5 \%)$ & \\
\hline At $3^{\text {rd }}$ month & - & - & \\
\hline $6^{\text {th }}$ month & - & $1(33.33 \%)$ & \\
\hline $12^{\text {th }}$ month & $1(100 \%)$ & $42(66.66 \%)$ & \\
\hline Total & $2(.66 \%)$ & $3(2.5 \%)$ & 0.3263 \\
\hline
\end{tabular}

\section{Safety}

In terms of untoward events which were to be accounted in terms of venous thromboembolism, myocardial infarction, pulmonary embolism, coagulopathy and Sudden death were not observed in any of the subjects of both the groups during the entire course of study.
Table 8: Reasons for discontinuation at the end of 12 months.

\begin{tabular}{|llll|}
\hline $\begin{array}{l}\text { Reasons } \\
\text { (overlapping) }\end{array}$ & $\begin{array}{l}\text { Ormeloxifene } \\
\mathbf{N}=120\end{array}$ & $\begin{array}{l}\text { COC } \\
\mathbf{N}=120\end{array}$ & p value \\
\hline Side effects & $2(1.66 \%)$ & $11(9.16 \%)$ & $0.0050 \dagger$ \\
\hline $\begin{array}{l}\text { Menstrual } \\
\text { irregularities }\end{array}$ & $5(4.16 \%)$ & $4(3.33 \%)$ & 0.3693 \\
\hline $\begin{array}{l}\text { Desire to } \\
\text { conceive }\end{array}$ & $5(4.16 \%)$ & $8(6.66 \%)$ & 0.1948 \\
\hline $\begin{array}{l}\text { Psychosocial } \\
\text { reasons }\end{array}$ & $19(16.66 \%)$ & $2(15.38 \%)$ & $0.0000 \dagger$ \\
\hline
\end{tabular}

\section{Side effects}

Bloating was the most common symptom in COC group $10(8.84 \%), 16(14.81 \%)$ and $4(3.73 \%)$ at 3,6 and 12 months.

Nausea was also a common side effect of COC which occurred in $8(7.07 \%), 6(5.55 \%)$ and $2(1.8 \%)$ of women at 3, 6 and 12 months. Breast discomfort in COC group was observed in $5(4.42 \%), 9(8.33 \%)$ and $3(2.80 \%)$ at subsequent study follow up respectively.

In ormeloxifene vaginal discharge was the most common side effects seen in $4(3.33 \%), 8(6.89 \%)$ and $2(1.75 \%)$ at 3, 6 and 12 months. Other side effects like mood disorders, weight gain, loss of libido and others occurred in in $1-5 \%$ of women which reverted to normal by end of the study.

Table 9: Satisfaction levels.

\begin{tabular}{|llll|}
\hline Particulars & Ormeloxifene N=120 & COC N=120 & p value \\
\hline Satisfied & $93(77.5 \%)$ & $78(65 \%)$ & $0.0162 *$ \\
\hline Satisfied and would recommend to others & $88(94.62 \%)$ & $56(71.79 \%)$ & $0.0000^{*}$ \\
\hline Satisfied but opted for another method & $5(6.02 \%)$ & $22(28.20 \%)$ & $0.0003 *$ \\
\hline Not satisfied and would not recommend & $27(22.5 \%)$ & $42(35 \%)$ & $0.0162 *$ \\
\hline
\end{tabular}

\section{Satisfaction levels}

The study observation shows significance for the statistical differences with higher level of satisfaction reported with $77.5 \%$ in the ormeloxifene compared to $65 \%$ of COCs (Table 9).

\section{DISCUSSION}

\section{Demographic profile}

Majority of women were of age 18 to 28 years in both the groups. Majority of women enrolled in either group were educated and resided in rural areas and working as housewives.

\section{Obstetrical profile}

Overall spontaneous abortion was documented more than induced abortion. Mean POG was 6.21 0.8 and $6.73 \pm 0.87$ in ormeloxifene and COC respectively.

\section{Pre-initiation, initiation and follow-up findings}

Mean BP (SBP/DBP) and mean values of all the laboratory investigations for both the groups were within normal limits at the beginning as well as at the end of study. Follow up was scheduled at $2^{\text {nd }}$ week, $3^{\text {rd }}, 6^{\text {th }}$ and $12^{\text {th }}$ month from the time of initiation of first dose. The $2^{\text {nd }}$ week follow up was important to ensure compliance 
and address side effects or any complications. All the women had complete abortion.

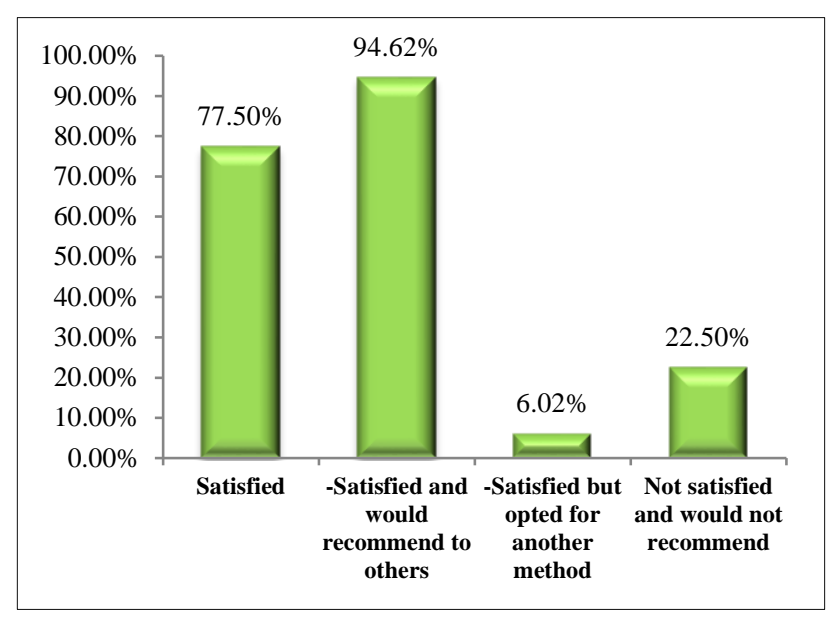

Figure 2: Satisfaction levels for ormeloxifene.

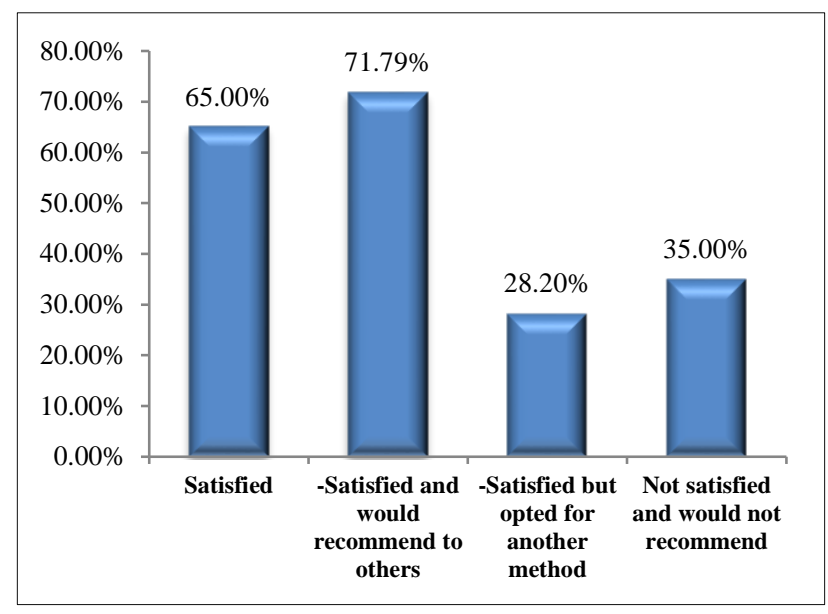

Figure 3: Satisfaction levels for COC.

\section{Effectiveness}

In the present study authors found in women using ormeloxifene that there was 1 method failure (MF) and 1 user failure (UF) both at 12 months of the study. The difference was statistically insignificant. Similar finding was observed in the latest study by Nair $\mathrm{H}$, which reported 4 user failures in first 3 month and 7 method failures at $9^{\text {th }}$ month with the pearl index of (PI) 2. Lower failure rates were also observed in the independent studies by Rajan R reporting $2 \mathrm{MF}, 3 \mathrm{UF}$; by Ghosh B reporting $1 \mathrm{MF}$ and $2 \mathrm{UF}$ and Rajpal $\mathrm{M}$ showing no failure rates.

In contrast higher failure rates were reported from the study of Nityananda S et al, with 6 method failure and 24 user failure, probably due to the higher number of subjects in the study. ${ }^{4}$ The pearl index in this study is 0.83 which is the lowest value seen among all the previously reported studies on ormeloxifene as a post abortion contraceptive method. The study showed 1 method failure and 1 user failure in the ormeloxifene group while no method failure and 3 user failures were reported in COC group. There was no significant statistical difference observed.

\section{Safety}

No untoward events were observed in any of the subjects in both the groups during the entire study. There are past studies showing certain unacceptable health risks with COC use which includes myocardial infarction, overt hypertension, ischemic or hemorrhaging strokes, venous thromboembolism, cerebral vein thrombosis, and overall cancer risk. ${ }^{5-8}$ However the absolute risks and direct attribution has been found to be unusual and not associated in most of the recent studies. Different studies following ormeloxifene have not shown any documented adverse reactions. ${ }^{9}$

None of the women reported of any unacceptable adverse side effects in either group. On the basis of the following observations and results from the present study, ormeloxifene stands as a comparable option to combined hormonal pill for contraception with a safe, effective and acceptable characteristics.

\section{Side effects}

It is of utmost importance to know the side effects of the OCPs in order to decrease the discontinuation and rather optimize its usage and adherence to provide more effective contraception. The following were the side effects in the study;

\section{Bloating}

This side effect was reported in $<1 \%$ of ormeloxifene users throughout the study. while it occurred in $7.07 \%$, $5.55 \%$ and $1.8 \%$ of COC group at 3,6 and 12 months.

\section{Nausea and/or vomiting}

It was observed that nausea vomiting occurred only in $1.66 \%$ of women using ormeloxifene at 3 months of use. However, in COC users this side effect was the $2^{\text {nd }}$ most common which occurred at 3,6 and 12 months at the rates of $8.84 \%, 14.81 \%$ and $3.73 \%$. The Khan MA and Mahin studies observed $23.4 \%$ and $16 \%$ of women using $\mathrm{COC}$ with side effects of nausea.

\section{Breast discomfort}

Vague breast discomforts were complained by only 2 women at the beginning of follow-up which could not be attributed to the pill as such. And none of the women further had breast discomfort in the ormeloxifene group. It is a well-known fact that COC can cause breast discomfort. In this present study in 5 (4.42\%), 9 (8.33\%) and $3(2.8 \%)$ of women breast discomfort was observed in the follow up at 3, 6 and 12 months. The Rosenberg et 
al study showed breast discomfort in $54-55 \%$ of women while Mahin study reported the side effect only in $4 \%$ of women.

\section{Abnormal discharge (excess, foul smelling or associated with itching)}

In ormeloxifene group $3.33 \%, 6.89 \%$ and $1.75 \%$ of women complained of abnormal vaginal discharges at 3 , 6 and 12 months. This side effect was observed in $2.65 \%$ to less than $1 \%$ at 3 and 6 months of use with no complaints by the end of the year. The study Mahin observed

\section{Mood disorders (negative effects: sad, anger)}

Only 1 woman taking ormeloxifene had mood disorder. While in COC $3.53 \%, 4.62 \%$ and $2.80 \%$ women had mood disorders at 3, 6 and 12 months. It was observed in Mahin study that $35.5 \%$ of women had anger mood disorders.

\section{Headache and giddiness}

This side effect was reported randomly and not confined to any cycle. In the present study 2,1 , and 1 woman using ormeloxifene had nausea at 3-month, headache at 6 month and giddiness at 12 months. It was also observed in the study of Nair H that 1,1 and 2 women had nausea, headache and giddiness respectively. The khan study showed $57.40 \%$ of women with giddiness as a side effect which was much higher than this study.

\section{Weight gain}

In women taking COC mean weight in this study was $55.03 \pm 2.1$ to $60.13 \pm 2.1$ at pre-initiation and at the end of the study respectively which was found to be statistically of significant difference.

This was similar to the study of suthipongse showing statistically significant difference and obvious weight gain with $53.1 \pm 6.8$ at pre- initiation and $54.1 \pm 6.4$ at the end.

\section{Migraine}

None of the women in either group complained of this side effects

\section{Ovarian cyst}

In one woman of the ormeloxifene group during follow up at 6-month ultrasound (USG) finding (done in patients interest following complaints of menstrual irregularities) showed an ovarian cyst of size $4.5 \mathrm{~cm}$.

The size of the cyst was normal on repeat USG done after 6 weeks.

\section{Others}

No other side effects were documented in this study in both the groups. There have been reports of acne in $43 \%$ and $5 \%$ in the studies Mahin and loudon respectively. In the study Rajpal, $14 \%$ and $4 \%$ women using ormeloxifene had mid-cycle pain and backache.

\section{Continuation rates}

The continuation rates of ormeloxifene were $100 \%$, $98.33 \%$ and $91.66 \%$ at 3,6 and 12 months respectively. Only limited studies on continuation have been studied for this pill. And this study finding was found consistent to the study of Nair $\mathrm{H}$ with the continuation rates as $100 \%, 97 \%, 93 \%$ and $84 \%$ at 3, 6, 9 and 12 months as shown in Table 10.

\section{Table 10: Studies and continuation rates in COC users.}

\begin{tabular}{|ll|}
\hline Studies & Continuation rates \\
\hline \multirow{2}{*}{ Loudon et al } & $\begin{array}{l}98,98,98,89,86,86 \% \text { at cycles } 1, \\
2,3,4,5,6 \text { respectively }\end{array}$ \\
\hline Mahin et al & $\begin{array}{l}88.96,58.01,44.59 \% \text { at } 1,6,12 \\
\text { months respectively }\end{array}$ \\
\hline Ramos et al & $89.8,84.8,74.8 \%$ at $3,6,12$ months \\
\hline Westhoff et al & $61 \%$ at 3 months; $43 \%$ at 6 months \\
\hline Khan et al & $57 \%$ at 6 months \\
\hline Present study & $100,95,75 \%$ at $3,6,12$ months \\
\hline
\end{tabular}

On comparing both the study groups ormeloxifene had higher continuation rates than COC. It's in patients best interest that the factors are addressed early as studies have shown that intervention of motivation did not have much significant effect on oral contraceptive continuation. ${ }^{10}$ In contrast the study by Shu-Ping Hou of 2015 concluded that the use of COCs in post abortion period had low continuation rates despite the pre-abortion contraceptive counselling. ${ }^{11}$ The satisfaction level depicting the acceptability was $93(77.5 \%)$ and $78(65 \%)$ in ormeloxifene and COC respectively with statistically significant difference $[\mathrm{p}=78(65 \%)]$. Continuation rates decreased with time for both the groups.

\section{Reasons for discontinuation}

In COC group side effects were the reason for discontinuation in $11(9.16 \%)$ of women. The most common reason for discontinuation in ormeloxifene group was psychosocial reasons, 19 (16.66\%). All other reasons for discontinuation accounted for $1-5 \%$.

\section{Acceptability}

Among the ormeloxifene users $88.29 \%$ were satisfied and accepted the method of contraception for continuation. Although in this study the schedule was acceptable there were few subjects who considered having the pills in 
interrupted manner which lead to high tendency of forgetfulness and missing it. And it has been seen in previous studies that lesser dosing schedule being the unique feature of the method is often easily forgotten. ${ }^{12}$ Among the women using COC, 68\% had accepted the method with satisfactory level to continue it further for contraceptive use. In a recent review by Tripney et al. it was observed that greater acceptance for modern contraceptive methods were higher in post-abortal women when they were counselled prior, and had support from their friends and family. ${ }^{13,14}$ The study showed a statistically significant difference in the comparison signifying a higher acceptability towards ormeloxifene. mostly attributing to the lesser number of side effects as well as the favorable menstrual patterns experienced. Statistically significant difference was seen in women of ormeloxifene users willing for recommend.

Despite the certain significant side effects and widely varying menstrual cycle patterns, women accepted ormeloxifene well.

\section{CONCLUSION}

Both the hormonal, combined hormonal contraceptive [combined oral contraceptive (COC), MALA-N] and the non-hormonal, centchroman (ormeloxifene) oral contraceptive pills are safe, effective, well tolerated and not associated with adverse outcomes when used immediately after abortion - whether induced or spontaneous. Laboratory investigation remains unaffected with the use of both the groups of OCPs. More menstrual irregularities but lesser side effects were observed in centchroman group than in COC group. Missed pill patterns were observed more in COC group than the centchroman group. The continuation rates of the pills in both the groups decreased in trend with time. Clinical outcomes are not affected by type of abortion, method of abortion and period of gestation. Satisfaction levels were higher with the non-hormonal pill, centchroman compared to COC.

\section{Funding: No funding sources}

Conflict of interest: None declared

Ethical approval: Not required

\section{REFERENCES}

1. WHO library cataloguing-in-publication data, unsafe abortion: global and regional estimates of the incidence of unsafe abortion and associated mortality in $2008,6^{\text {th }}$ ed.; 2011. Available at: https://www.who.int/reproductivehealth/publications/un safe_abortion/9789241501118/en/. Accessed on $22^{\text {nd }}$ February 2020.

2. Baldaszti E, Wimmer-Puchinger B, Loschke K. Acceptability of the long-term contraceptive levonorgestrel-releasing intrauterine system (Mirena): a 3-year follow-up study. Contracept. 2003;67:87-91.

3. Postpartum IUD Reference Manual. New Delhi, India: Planning Division, Ministry of Health and Family Welfare Government of India; 2018. Available at: https://nhm.gov.in/New_Updates_

2018/NHM_Components/RMNCHA/Family_planning/ Schemes_\&_Guidelines/IUCD/IUCD_Manual_English. pdf. Accessed on $22^{\text {nd }}$ February 2020.

4. Nair HS, Jayasimhan P. A prospective study of centchroman users with special reference to its contraceptive benefit. J Evid Based Med Healthc. 2016;3(98):5374-80.

5. Lidegaard $\varnothing$, Løkkegaard E, Jensen A, Skovlund CW, Keiding N. Thrombotic stroke and myocardial infarction with hormonal contraception. N Engl J Med. 2012;366(24):2257.

6. Haemorrhagic stroke, overall stroke risk, and combined oral contraceptives: results of an international, multicentre, case-control study. WHO collaborative study of cardiovascular disease and steroid hormone contraception. Lancet. 1996;348(9026):505.

7. Siritho S, Thrift AG, McNeil JJ, You RX, Davis SM, Donnan GA. Risk of ischemic stroke among users of the oral contraceptive pill: The Melbourne Risk Factor Study (MERFS) Group. Stroke. 2003;34(7):1575-80.

8. Iversen L, Sivasubramaniam S, Lee AJ, Fielding S, Hannaford PC. Lifetime cancer risk and combined oral contraceptives: the Royal College of general practitioners' oral contraception study. Am J Obstet Gynecol. 2017;216(6):580-e1.

9. Ganguli G. Mukherjee K. Raman N. Centchroman, a safe contraceptive coverage following medical termination of pregnancy. J Obstet Gynecol. 1995;64965.

10. Berenson A B, Rahman M. A randomized controlled study of two educational interventions on adherence with oral contraceptives and condoms. Contracept. 2012;86(6):716-24.

11. Hou SP, Zhu WL, Li SM, Teng YC. Acceptance and continuation of contraceptive methods immediate postabortion. Gynecol Obstet Investigat. 2017;82(1):8695.

12. Yadav VK, Sharma $\mathrm{P}$, Sharma $\mathrm{R}$, Yadav J. Centchroman a better alternative for hormonal oral contraceptive pills. Int J Pharm Bio Sci. 2011;2(1):58792.

13. Tripney J, Kwan I, Bird KS. Postabortion family planning counseling and services for women in lowincome countries: a systematic review. Contracept. 2013;87:17-25.

14. Rose SB, Cooper AJ, Baker NK, Lawton B: Attitudes toward long-acting reversible contraception among young women seeking abortion. J Womens Health (Larchmt). 2011;20:1729-35.

Cite this article as: Miuli I, Dewan R, Agarwal K. A study to compare acceptability, safety and continuation rates of combined hormonal pill and centchroman as post abortion contraceptives. Int $\mathbf{J}$ Reprod Contracept Obstet Gynecol 2020;9:3350-9. 


\section{ANNEXURE- 1}

\section{INFORMED CONSENT FORM}

Study Title: "Comparison of acceptability, safety and continuation rate of combined oral hormonal pill and centchroman as post abortal contraceptives"

\section{Subject number/ ID:}

I confirm that I have read and understood the information sheet for the above study and have had the opportunity to ask questions.

I have been fully explained about the methodology, advantages and risks involved.

I understand that the participation in the study is voluntary and I reserve my rights to withdraw from study whenever I wish.

I do hereby give my consent for participation in the study. I also agree to allow use of data arising from this study for scientific purposes without disclosing my identity.

Signature/ left thumb impression of participant:

Date:

Place:

\section{Name of participant:}

Signature of witness

Name of witness:

Signature of investigator: 